\title{
Türk Ordusunun Sermaye ile İlişkisi ve Ordu-Siyaset İlişkisinin Dönüşümü
}

\author{
The Relationship of the Turkish Army with Capital and the Transformation of the \\ Military-Politics Relations
}

\section{ABDULLAH KÖKTÜRK*}

* Asst. Prof., Piri Reis University, Maritime Higher Vocational School, Postane Mahallesi, Eflatun Sk. No:8, 34940 Tuzla, İstanbul, Turkey, E-mail: akokturk@pirireis.edu.tr

(D) https://orcid.org/0000-0003-2706-6678

Öz: Türkiye son altmış yıl içinde ikisinde askerlerin yönetime el koyduğu, ikisinde ise iktidarın değiştiği dört 'başarılı' askeri müdahale yaşamıştır. Bunlara, Albay Talat Aydemir'in müdahale girișimleri ve 15 Temmuz kalkıșması da dâhil edilirse, ülke üç başarısız askeri müdahale girişimine sahne olmuştur. Türk Silahl Kuvvetleri askeri müdahaleler aracılığıyla Türk siyasi yașamında etkili bir karakter olmayı başarmıștır. Ordunun siyasi hayattaki nüfuzu ekonomik hayatta da karşımıza çık-maktadır. Bu çalışmada Türk ordusu ve sermaye arasındaki ilişki siyasi süreçler dâhilinde ele alınılmıştır. Bu bağlamda çalışmada Türk ordusu ve sermaye arasındaki ilişkiye Ordu Yardımlaşma Kurumu (OYAK) ve diğer askeri vakıf şirketleri yönetim kurulları üzerinden bakılmıştır. Bu şirketlerdeki yönetim kurullarındaki emekli üst rütbeli subayların dağılımı ve asker/sivil oranlarındaki değiş̧me üzerinden Türk Silahlı Kuvvetleri ve siyaset ilişkisi incelenmiştir.

Anahtar kelimeler: Türk Silahlı Kuvvetleri, Askeri müdahale, Sermaye, Ordu-Siyaset ilişkisi, Ordu Yardımlaşma Kurumu

Abstract: Turkey has experienced four "successful" military interventions in the last 60 years. The military took over in two interventions while in the other two attempts the governments were toppled. The country also experienced three failed military interventions, if we count the July 15th coup attempt and Colonel Talat Aydemir's coup attempts. Turkish Armed Forces has become an important actor in Turkish politics through military interventions. The military's political presence also over-flows to the economical life in Turkey. This study discourses the relations between the Turkish military and the capital. Therefore, the study cites the managements of various military companies that include Military's Pension Fund. This study addresses to the relations between the Turkish military and the capital. Therefore, the study reviews the managements of various military companies that include Military's Pension Fund. The paper examines the relation of Turkish Armed Forces with the Turkish politics through the weight of military to civilian personnel in the management of these companies.

Keywords: Turkish Armed Forces, Military intervention, Capital, Military-Political relations, Military's Pension Fund 


\section{Giriş}

Türkiye'de ordu, Osmanlı'dan beri siyasi, ekonomik ve sosyal hayatı etkileyen önemli bir bürokratik kurum olmuştur. Ordu cumhuriyetin kuruluş aşamasından itibaren de kurucu kadrolarının yetiştiği bir yer olarak devlet içindeki önemini korumuştur. Hem rejimin uygulamalarına işlerlik kazandırılmasındaki rolü, hem de eski kadrolarının yönetici bürokrasi içinde yer alması ile ordu 1920'li yıllarda iktidar blokunun önemli unsurlarından birisini oluşturmuştur.

İkinci dünya savaşı ortamında ve sonrasında dünya konjonktürünün de değişimi ile bu önemini kaybeden ordu, 1960’lı yıllardan başlayarak 90'lı yılların sonuna kadar tekrar siyasette önemli bir aktör olmuştur. Bu dönemde ordunun yaptığı müdahalelerin siyaseti olduğu kadar ekonomiyi de etkilediği düşünülmektedir.

Türkiye'de askeri müdahaleleri inceleyen çalışmaların birçoğunda (Birsen Örs, Ahmet İnsel, Ali Bayramoğlu, İsmet Akça, Ümit Cizre, Serap Yazıcı, Ayşe Gül Altınay) genellikle askeri bürokrasinin pretoryenist ${ }^{1}$ ve militarist bir bakışla silahlı gücünü kullanarak siyaset üzerinde hâkimiyet kurma eğiliminde olduğu vurgulanmaktadır.

Bu çalışmada, ordunun askeri müdahalelere sadece pretoryenist amaçlarla başvurmadığını, bu müdahalelerin ardında ekonomik ve sınıfsal gerekçeler olduğu hipotez olarak savunulacaktır. Yine bunun bir alt hipotezi de, ordu ve sermaye arasında bir ilişki olduğudur. Türkiye'de askeri müdahaleler ile birikim rejimleri arasındaki ilişki, ya da en azından bunların ekonomik büyümeye etkisi tartışılmaya devam etmektedir.

Bir diğer hipotez, şirket yönetim kurullarında görev alan emekli üst rütbeli subayların ordu-sermaye ilişkisinin kurulmasında veya var olan ordu-sermaye ilişkisinin daha da derinleşmesinde rol oynadığıdır.

Bu çalışmada Türk ordusu ve sermaye arasındaki ilişki, siyasi süreçler dâhilinde ele alınmıştır. Bu bağlamda çalı̧̧mada Türk ordusu ve sermaye arasındaki ilişkiye Ordu Yardımlaşma Kurumu (OYAK) ve diğer askeri vakıf şirketleri yönetim kurulları üzerinden bakılmıştır. Çalışmanın ana hipotezi, 2011 yılından sonra ordusiyaset ilişkisinin dönüştüğüdür. Bunu sinamak için askeri şirketlerdeki yönetim kurullarındaki emekli üst rütbeli subayların dağılımı ve asker/sivil oranlarındaki yıllar içindeki değişim üzerinden Türk Silahlı Kuvvetleri ve siyaset ilişkisindeki dönüşüm incelenerek, 2011 yılındaki kırılmanın sebepleri irdelenecektir.

Çalışma nitel araştırma tekniği kullanılarak gerçekleştirilmiştir. Çalışmada belge ve doküman incelemesi tekniği kullanılarak veriler elde edilmiştir. Bu bağlamda bilhassa yönetim kurullarında görev alan üyelerin verilerini elde etmek amacı ile Türkiye Ticaret Sicili Gazetesi arşivleri, Kamuyu Aydınlatma Platformu (KAP) raporları ve TSKGV ile OYAK'a bağlı şirketlerin yıllık faaliyet raporları incelenmiştir. Bu incelemeler sonucunda yönetim kurullarında görev yapan kişiler tespit edilmiştir. Bu kişilerden hangilerinin sivil, hangilerinin emekli subay olduğu belirlendikten sonra çeşitli oranlamalar yapılarak bunun ordu siyaset ilişkisine etkisi irdelenmiştir.

${ }^{1}$ Pretoryenizm: Askerlerin kendilerini devletin ve rejimin koruyucusu olarak görmeleri, ellerindeki silahlı güç ile siyaseti yönlendirmeleri. 
Çalışmanın yöntemi tümevarım olarak tarihsel maddeci yöntemdir. Bu yönteme göre, toplumların alt yapısında ekonomi vardır. Siyaset, hukuk, askerlik gibi üst yapılar bunun üzerinde şekillenir. Yani üretim süreci, üretim ilişkileri üzerinde belirleyici etkiye sahiptir. Ancak kısa süreler ile üst yapının alt yapıyı kontrol etmeye çalıştığ 1 da görülür. Türkiye'de son 10 yıldır siyaset tüm üst yapı kurumları gibi ekonomide de tahakküm kurmaya çalışmaktadır. Bu durum ordu-sermaye arasındaki ilişkiyi de etkilemektedir.

Yine bu yönteme göre; askeri müdahalelerin altında yatan en önemli etken ekonomiktir. Daha açık olarak, sermaye birikim rejimi süreçleri müdahaleleri etkilemiştir. 1960 müdahalesi süregelen bir birikim rejimini hızlandırmış, 12 Eylül müdahalesi ise yeni başlamış bir birikim rejiminin işlemesini kolaylaştırmıştır. 12 Mart ve 28 Şubat müdahaleleri ise süregiden birikim rejimlerinde oluşan krizleri sanayi sermayesi lehine çözmüşlerdir.

Çalışmanın kavramsal çerçevesini oluşturabilmek amacı ile, tarihsel süreçler içinde Türkiye'de ordunun siyaset karşısındaki konumuna bakılmıştır. Ardından siyasi dönüşümler bağlamında Türk ordusu ve sermaye ilişkisi ele alınmıştır. Türk ordusunun gerçekleştirdiği askeri müdahalelerle Türk siyasi ve ekonomik hayatında nasıl önemli bir aktör haline geldiği ve askeri müdahalelerin ülke ekonomisini ne şekilde etkilediği incelenmiştir. Son olarak emekli üst rütbeli subayların çoğunun şirketlerinde görev aldığı OYAK ve TSK Güçlendirme Vakfı şirketleri yönetim kurulları üzerinden ordu-siyaset ilişkisinin dönüşümü ele alınmıştır.

\section{Türkiye'de Ordunun Tarihsel Konumu}

Türk ordusunun tarihsel mirasında toplum ve devletle özdeşleşme yanında, siyasete müdahale geleneği etkin olarak göze çarpmaktadır.1826'da ortadan kaldırılana kadar Yeniçerilik kurumu siyasette etkin olmuş, padişahların iktidardan indirilmesinde bile görev almıştır. XVII. Yüzyıldan itibaren esnaf loncalarına katılan yeniçeriler ekonomik alanda da etkin olmuşlardır. ${ }^{2}$ Yeniçeriliğin II. Mahmut tarafından 1826'da kanlı bir şekilde kaldırılmasından sonra ordunun yapısı büyük ölçüde değişime uğramıştır. Merkezi bürokrasi de güçlendirilerek ordunun siyasileşmesi engellenmeye çalışılmıştır.

Ordu, Osmanlı Devleti'nin gerileme döneminden itibaren siyasette daha fazla etkin olmaya başlamıştır. 1859 Kuleli Olayı ve 1876'da Abdülhamid'i anayasa ilanına zorlayanların başında Harp Okulu Komutanı Süleyman Paşa'nın olması bu dönemde askerlerin siyasetteki etkisini göstermektedir. Abdülhamid'e karşı muhalefet de yine askerler arasında doğmuş, 1889'da sonradan İttihat ve Terakki Cemiyeti adını alacak, Osmanlı İttihat Cemiyeti dört askeri tıp öğrencisi tarafından kurulmuştur. ${ }^{3} \mathrm{Bu}$ dernek ordu içinde teşkilatlanarak 1908'de II. Meşrutiyetin ilanı da sağlayacaktır.

Türk ordusunun bugüne kadar göz ardı edilen bir özelliği de tarihi boyunca güçlünün yanında mevzilenmiş olmasıdır. İttihat ve Terakki'nin Abdülhamid'e karşı çıkması onun iktidarının zayıflaması dolayısı iledir. İttihat Terakki döneminde uygulanan 'Milli İktisat' politikasının ana amacı gayrı Müslümlere karşı Türk eşrafın zenginleşmesidir. İttihat Terakki yönetimi; Batı milli burjuvazisinin liberalizmin

${ }^{2}$ Bülent Çelik, "Yeniçerilerin Esnaflaşmasında Orducu Görevinin Rolüne Dair Bazı Tespitler”, Belgi Dergisi, 2/18 (2019), s.1688.

${ }^{3}$ William Hale, Türkiye’de Ordu ve Siyaset, çev., Ahmet Fethi, İstanbul: Hil Yayınları, 1996, s.38. 
serbest piyasası üzerinde yükseldiğini görerek, Milli İktisat politikasını yürütmek için liberal iktisatçı Cavit Bey’i Maliye Bakanlığı'na atamıştır. ${ }^{4}$

1914'de başlayan savaş, Osmanlı'nın yenilgisi ve İttihatçıların kendilerini tasfiyesi ile sonuçlandı. 30 Ekim 1918'de yapılan Mondros antlaşması ile yeni bir süreç başladı. 1919-1922 yılları arasında temelleri atılan yeni Türk Ordusu, Cumhuriyetin kuruluşunda ve reformların yapılmasında yeni rejimin yanında aktif roller üstlendi.

Türkiye Cumhuriyeti'nin kuruluşunda iktidar bloku; asker kontrolündeki bürokrasi liderliğinde, ticaret burjuvazisi ve büyük toprak sahiplerinden oluşmaktaydı. Ürünü toprak sahibi üretiyor, ticaret burjuvazisi bunun dağıtımını gerçekleştiriyor, hegemon durumdaki bürokrasi de bu sistemin yasal zeminini garanti ederek iktidarını sürdürüyor, kaynaklar da çoğunlukla bu üç grup arasında dağıtılıyordu. Ordunun cumhuriyetin kuruluşunda sisteme bağl1lı̆̆ 1 Atatürk'ün ve bürokrasinin gücünü hissetmesi nedeniyledir.

Ordunun cumhuriyetin kuruluşunda sermaye ile ilişkisinin cisimleşmiş göstergesi İş Bankası'dır. 1924 yılında kurulan İş Bankası'nın ilk yönetim kurulunun 10 üyesi vardır ve bunun beşi askerdir. İ ş Bankasının kuruluşu aynı zamanda 'affairism' tartışmalarını da beraberinde getirmişti. Şeker fabrikalarının kuruluşu ve şeker üretim ve ithalatının aynı kişilerce yapılması dolayısıyla üretimin düşürülerek, ithalatın arttırılması ve dolayısıyla da İş Bankası grubunun da içinde olduğu bürokrat/işadamlarınca alınan yüksek komisyonlar, Teşvik-i Sanayi Kanunu ile özel sektöre tanınan avantajlar, limanlarda kurulan özel şirketler aracılığı ile yapılan yolsuzluklar bu dönemin 'affairism' örneklerindendir. ${ }^{7}$

1935 senesinde, Ordu Dahili Hizmet Kanunu kabul edilmiştir. Bu kanunun askeri müdahalelerde dayanak olarak da kullanılan 34'üncü maddesinde "Silahlı Kuvvetlerin görevi Anayasa'da belirtilen Türkiye Cumhuriyeti'ni Türk Anayurdunu korumak ve kollamaktır” yazmaktadır. Bu görev, 1961 tarihli Türk Silahlı Kuvvetleri İç Hizmetleri Kanununun 35'inci maddesinde de tekrarlanmıştır. ${ }^{8}$

1944 yılında Genelkurmay Başkanlığı’nın önce Başbakanlığa, 1949 yılında ise Milli Savunma Bakanlığına bağlanması, Atatürk sonrası dönemin dönüm noktalarıdır. 1946 seçimlerinde bürokrasinin yerine iktidar blokunda hegemon duruma geçeceği görülen ticaret burjuvazisinin gücünü gören ordu, 1950 sonrası Demokrat Parti iktidarında Atatürk Devrimleri’nin ve laikliğin yıpratılmasına hatta irticanın güçlenmesine sessiz kalmıştır.

Tek parti dönemindeki ekonomik imtiyazlarını yetiren ordu, 1950’lerin ikinci yarısından itibaren Sanayi Sermayesinin yükselişine şahit olmuştu. Bu dönemin sermaye birikim rejimi olan İthal İkameci Sanayileşmenin hızlandırılması ve Sanayi

\footnotetext{
${ }^{4}$ Abdüllatif Şener, “İttihat ve Terakki Cemiyeti’nin İktisadi ve Mali Politikaları”, Hacettepe Üniversitesi İktisadi ve İdari Bilimler Fakültesi Dergisi, 8/1 (1990), s.209.

${ }^{5}$ M. Halis, Özer, “Cumhuriyetin İlk Yıllarında Millî Tüccar Oluşturma Çabalarında İş Bankası'nın Rolü”, Ankara Üniversitesi SBF Dergisi, 69/2 (2014), s.353.

${ }^{6}$ Affair: Fransızca iş anlamına gelmektedir. Affairism ise, çıkarcı anlamındadır. Aferizm Türkçeleşerek siyasi kadrolarla sermaye çevrelerinin kurduğu yakınlıkla devlet desteği ve kaynaklarından yararlanarak özel ekonomik girişimlerde bulunma anlamında kullanılmıştır.

${ }^{7}$ Doğan Avcıoğlu, Türkiye’nin Düzeni, 1. Kitap, İstanbul: Tekin Yayınevi, 11. bs., 1977, s.379-439.

${ }^{8}$ Bu madde 13/7/2013 tarihinde yapılan kanun değişikliği ile, değiştirilmiştir. Bkz. TSK İç Hizmet Kanunu, madde 35, erişim 26 Mart 2021, http://www.mevzuat.gov.tr/MevzuatMetin/1.4.211.pdf.
} 
Sermayesinin iktidar blokunda hegemon güç haline gelmesi, ordu içindeki darbeci odakların 27 Mayıs 1960'da harekete geçmeleri ile mümkün olabilmiştir.

27 Mayıs müdahalesi, 1950'lerden itibaren önemli bir ekonomik güç durumuna gelen sanayi sermayesinin üretim ilişkilerinde ve siyasette de önemli bir güç olmasını sağlamıştır. Sanayi Sermayesinin isteği olan, 'kaynakların devlet tarafından denetlenmesi' ve 'kaynakların sanayi sermayesine aktarılması' amacıyla Devlet Planlama Teşkilatı'nın (DPT) müdahalenin ilk aylarında kurulmasının 27 Mayıs yönetiminin ilk faaliyetlerinden olması, askerler ile Sanayi Sermayesi arasındaki ilişkiyi göstermektedir. Sungur Savran'a göre de “27 Mayıs'ın tarihsel anlamı siyasal üstyapının tarımsal/ticari sermaye birikiminden sınai sermaye birikimine geçişin ihtiyaçlarına uyarlanması" dır. ${ }^{9}$ Böylece kaynaklar ticaret veya tarıma değil Sanayi Sermayesine yönlendirilebilmiştir.

MBK'nin Sanayi Sermayesi yanlısı icraatları, sanayi ve ticaret odaları yönetim kurullarına sanayi sermayesi lehine müdahale ederek de kendini göstermiştir. MBK, Vehbi Koç ve Nejat Eczacıbaşı gibi iki önemli sanayiciyi İstanbul sanayi Odası'na başkan ve başkan yardımcısı olarak atamıştır. MBK hükümetinde Sanayi Bakanının kim olacağını da sanayici Vehbi Koç belirlemiştir. ${ }^{10}$

Ticaret ve Sanayi Sermayesi arasındaki mücadelenin MBK'ne yansıması, 27 Mayıs müdahalesinin daha 6 ayı dolmadan 14 MBK üyesi subayın, bir tür sürgün olarak, dünyanın çeşitli başkentlerine büyükelçilik müşaviri olarak atanmaları olmuştur.

1960-1971 zaman dilimi, İthal İkameci Sanayileşme modelinin yükselişe geçtiği bir dönem olmuştur. Bu dönemde bir yandan 1961 Anayasası ile siyasi iktidar sınırlandırılmış, bireysel özgürlükler güvenceye alınmış, özgürlükçü çoğulcu ve sosyal liberal bir süreç yaşanmıştır. Türkiye batılı anlamda liberal demokrasiye en çok bu dönemde yaklaşmıştır. Ancak kapitalizmin gelişim düzeyindeki zayıflık birikim sürecinde tıkanıklıklar oluşturmuş, buna bağlı olarak mevcut üstyapı kurumları geçerliliklerini yitirmişlerdir. Buna bağlı olarak sanayi burjuvazisinin kişisel özgürlüklerdeki gelişim ve toplu sözleşme düzeninden duyduğu rahatsızlık bu dönemin sonunu getirmiştir. Sistemin bu çelişkileri 12 Mart 1971'de bir kez daha ordunun müdahalesi ile çözülmeye çalışılmıştır.

12 Mart müdahalesi öncesi ordudaki bazı radikal subaylar 9-10 Mart gecesi hükümeti devirerek kökten bir reform programı uygulamayı düşünmüşlerdir. ${ }^{11} \mathrm{Bu}$ reformların bir tür sol-sosyalist parlamento dışı bir iktidarca yürütülmesi planlanmıştır. Doğan Avcıoğlu ve Mihri Belli’nin “Milli Demokratik Devrim” düşüncesi çevresince bazı aydınların da dâhil olduğu plan başarıya ulaşmayınca aralarında Tümgeneral Celil Gürkan ve Tuğamiral Vedii Bilget'in de bulunduğu beş general, bir amiral ve 35 albay 16 Mart 1971'de emekliye sevk edilmişlerdir. ${ }^{12} 12$ Mart 9 Mart hareketinin planlayıcısı olarak, 13 Kasım 1960'da sürgüne gönderilen MBK'nin radikal kanadından Numan Esin, İrfan Solmazer, Orhan Kabibay gibi bazı emekli subayların da olması dikkat çekicidir.

\footnotetext{
9 Sungur Savran, “1960, 1971, 1980 Toplumsal Mücadeleler, Askeri Müdahaleler”, 11. Tez Kitap Dizini, 6, İstanbul: Uluslararası Yayıncilık, 1987, s.136.

${ }^{10}$ Abdullah Köktürk, “Türkiye'de İktidar Bloğu'nun Değişim ve Dönüşümleri”, ICHES Uluslararası İnsani Bilimler ve Eğitim Bilimleri Kongresi Tam Metin Kitabı, Elazığ: Asos Yayınevi, 2019, s.700.

${ }^{11}$ Hale, Türkiye'de Ordu, s.162.

${ }^{12}$ Ali Gevgilili, Yükselişve Düşüş, İstanbul: Altın Kitaplar, 1981, s.466.
} 
9 Mart hareketi başarılı olamayınca da, 12 Mart 1971'de Genel Kurmay Başkanı ve Kuvvet Komutanları hükümete bir muhtıra vererek, hükümetin istifa etmesine neden olmuşlar ve Türkiye iki yıl boyunca Sanayi Sermayesine yakın bakanlar ve başbakanlarla yönetileceği iki yıllık bir ara rejim dönemine girmiştir.

12 Marttan sonra, benzerlerini 12 Eylül 1980'de göreceğimiz pek çok olay yaşanmıştır. Bunlar başlıca, emek üzerindeki baskılar, ücretlerin düşürülmesi, grevlerin yasaklanması, sendika liderlerinin hapsedilmesi, gençliğin önderlerinin hapsedilmeleri ve bazılarının idamı vb. dir.

12 Mart dönemi dediğimiz dönem, 12 Mart 1971'den, 1973 Ekim seçimlerine kadar geçen iki yıl olarak gözükse de CHP-MSP koalisyon hükümetinin yıkıldığ 1974 Kasım ayından sonra kurulan Sadi Irmak hükümeti de bu döneme dâhil edilebilir. 29 Kasım 1974 günü yapılan güven oylamasında 17 kabul oyuna rağmen, 358 red oyu ile meclisten güvenoyu alamamasına rağmen, 17 Kasım 1974 tarihinden, 31 Mart 1975 tarihine kadar 4.5 ay boyunca ülkeyi yönetmiştir.

Esasında 12 Mart 1971'de başlayan emeği baskılama programı, Aralık 1983'de Özal Hükümeti kurulana kadar (kısa süreli CHP-MSP koalisyon dönemi ayrı tutulursa) askerlerin kontrolünde devam etmiştir. 12 Mart dönemindeki Nihat Erim, Naim Talu, Ferit Melen ve sonraki Sadi Irmak hükümetlerindeki çoğu bakanın 12 Eylül hükümetlerinde de görev almaları bu programın devamını göstermektedir.

12 Mart ve 12 Eylül dönemlerindeki Bakanlar Kurullarının oluşumu incelendiğinde, 8 bakanın hem 12 Mart hem de 12 Eylül dönemlerinde görev aldıkları görülmektedir. Sivil yönetime geçiş kabul edilen Sadi Irmak hükümeti döneminde görev yapan bakanların 12 tanesi ya 12 Mart ya da 12 Eylül dönemlerinde görev almıştır. 12 Mart ve Sadi ırmak hükümetlerinin bu yapısı ile sürmekte olan ithal ikameci birikim rejiminin yaşadığı krizi bir müddet ertelese de, 1975-1980 arası "istisnai devlet"in sıkıyönetim gibi bazı özelliklerini de gösteren sivil hükümetler dönemindeki "olağan devlet" hegemonya krizini çözememiş ve bu kriz 12 Eylül 1980 iktidarı ile çözülmüştür. ${ }^{13}$

1973 sonrası kurulan koalisyon hükümetleri döneminde uygulanan popülist politikalar ile ücretlerin dünya ortalamasının üzerinde seyretmesi, döviz sıkıntısı, iç pazarın tıkanması ve ücret artışlarının işgücünün verimlilik artışı ile telafi edilememesi sonucu kâr oranlarının düşmesi ile iç pazara yönelik bir birikim modeli olan İthal İkameci Sanayileşme modelinin krize girmesi sanayi sermayesinin tam hegemonya kurmasını engellemiştir. Bu koşullarda İhracata Yönelik Sanayileşme adı verilen yeni bir birikim modeli 24 Ocak 1980'de bir istikrar programı ile yürürlüğe girmiştir. Ancak 24 Ocak Programının, iş adamlarınca yürürlükteki sendika, toplu sözleşme kanunları, süregelen grev ve işçi eylemleri gölgesinde olumlu sonuçlar vermeyeceği düşüncesi ve 70'lerden itibaren yükselen sınıfsal mücadelenin burjuvazi tarafından kendisine karşı bir tehdit olarak görülmesi, 12 Eylül Askeri Müdahalesinin gerekçelerini oluşturmuştur. ${ }^{14}$

12 Eylül'den sonra kurulan ve E. Ora. Bülent Ulusu'nun başbakan olduğu hükümette, 24 Ocak Kararlarının sorumlularından Turgut Özal'ın başbakan yardımcı-

\footnotetext{
${ }^{13}$ Abdullah Köktürk, Türkiye’de Ordu ve Sermaye İlişkisi, Ankara: Nobel Bilimsel Eserler, 2. bs., 2019, s.147148.

${ }^{14}$ Köktürk, Türkiye'de Ordu, s.156.
} 
lığına getirilmesi ve bizzat Başbakan Ulusu tarafından TÜSİAD üyelerinden istenen birçok şirket yöneticisinin yeni hükümette bakan olarak yer alması Kasım 1983 seçimlerine kadar sürecek ara rejimden büyük sanayici ve iş adamlarının memnun kalmasını sağlamıştır.

Ordunun fiili olarak siyasal iktidarı elinde bulundurduğu 1980-1983 dönemi, Türkiye'nin hızla neoliberal politikalara eklemlendiği bir dönem olmuştur. Bu dönemde İhracata Yönelik Sanayileşme sermaye birikim rejimine geçilirken devlete hâkim olan ordu "stratejik seçiciliğini"15 büyük sanayi sermayesi lehine kullanmıştir. $^{16}$

12 Eylül'den itibaren sanayi sermayesinin ittifakı haline gelen ordu, iktidar blokunda kısa süreli ticaret sermayesinin hâkimiyetinin kurulduğu 1996-1997 yıllarında irtica ile mücadele adı altında, kültürel ve ideolojik söylemler de kullanarak siyasete müdahalede bulunmuş ve 28 Şubat sürecinde Necmettin Erbakan Hükümeti’nin iktidardan uzaklaştırılmasını ve Refah Partisi'nin kapatılmasını sağlamıştır. RP yerine kurulan Fazilet Partisi'nden (FP) kopan bir grubun kurduğu Adalet ve Kalkınma Partisi'nin (AKP veya AK Parti) 2002 seçimlerinden tek başına iktidar olarak çıkmasında 28 Şubat sürecinde oluşan tepkilerle muhafazakâr kitlenin AK Parti'ye yönlendirilmesinin de katkısı olduğu değerlendirilebilir.

\section{OYAK, TSKGV Şirketleri ve Askeri Vakıflar sayesinde Sermaye ile Kurulan iliş̧ki}

Kapitalist ülkeler, toplumun belirli bir kesiminin üretim araçlarına sahip olduğu sınıf temelli toplumlardır. Üretim araçlarına sahiplik durumu, üretim ilişkilerinin yapısını ve o sınıfın devlet ile ilişkilerini belirler. Çünkü üretimden kimin ne kadar pay alacağı, kaynakların kime ne kadar dağıtılacağı, yani iktidar ilişkilerinin özü bu üretim ilişkileri ve üretim araçları sahipliği sonucu belirlenir.

Sınıfları Marx ve Weber ayrı ayrı incelemişlerdir. Tarihsel materyalist yaklaşımda üretim ilişkileri önemli iken, Weber'de piyasa önem kazanmıştır. Weber sınıflara mesleki farklılıklar ve sosyal statü üzerinden bakmıştır. Weber'e göre, insanların eğitimi, meslek ve yaşama biçimleri sosyal statülerini belirler. Yine ona göre, sinıf konumu, kişilerin mal ve yaşam koşulları gibi kişisel yaşantıları için sahip oldukları tipik olanaklar demektir. ${ }^{17}$

Türkiye'de TSK mensupları 1960'lara kadar meslek grupları hiyerarşisi içinde Weberyen anlamda, subay/astsubay "zümre”sini oluşturmuşlardır. Ancak bu zümre OYAK'ın kurulması ve üretim araçlarına sahip olmayla beraber sınıf özellikleri göstermeye başlamıştır. ${ }^{18}$

Askeri müdahaleler ile birikim rejimleri arasında ilişki kuran az sayıdaki yazardan birisi olan İsmet Akça, Bob Jessop'un 'Stratejik İlişkisel Yaklaşım’ yöntemini kullanarak yazdığ 1 çalışmasında "OYAK'ın kurulmasıla (...) ordunun kapitalist ekonomiye eklemlenmesinde doğrudan bir mekanizma tesis edildiğini" savunmaktadir. ${ }^{19}$

${ }^{15}$ Bob Jessop'un stratejik seçicilik kavramı için bkz. Bob Jessop, “Accumulation Strategies, State Forms, and Hegemonic Projects", Kapitalistate, 10/11 (1983), s.101.

${ }^{16}$ Köktürk, Türkiye'de Ordu, s.163.

${ }^{17}$ Max Weber, Sosyoloji Yazıları, çev., Taha Parla, İstanbul: Deniz Yayınları, 2008, s.282-283.

${ }^{18}$ Abdullah Köktürk, “Militarizmin Öteki Yüzü: Askeri Şirketler”, Ayrıntı Dergisi, 31 (2019), s.88.

${ }^{19}$ İsmet Akça, "Ordu, Devlet ve Sınıflar: 27 Mayıs 1960 Darbesi Örneği Üzerinden Alternatif Bir Okuma 
1960'lı y1llardan itibaren emekli askerlerin bilhassa banka ve sanayi şirketlerinde istihdam edilmeleri 2000'lere kadar doğal karşılanmıştır. Ayrıca, savunma harcamalarının oldukça yüksek olduğu Türkiye'de, bu paranın kullanımında siyasete yön verenlerin üst rütbeli askerler olduğu düşünüldüğünde, incelenmesi gereken ayrı bir parasal ilişki olduğu görülmektedir.

Askeri vakıflar ve bunlara bağlı şirketlerde, askeri gemi üreten özel tersaneler dahil savunma sanayi ile ilgili şirketlerde ve OYAK'a bağlı şirketlerin yönetim kurullarında görev alan emekli askerler TSK'nın sermaye ile ilişkisinin bir diğer yüzünü oluşturmaktadır.

OYAK, 3 Ocak 1961'de 205 nolu yasa ile kurulmuş ${ }^{20}$ ve bu kanun ile TSK'nın büyük sermaye ile ilişkisinin garanti altına alınmıştır. OYAK bugün 420 bin üyesi ve 32 bin çalışanı ile Türkiye'nin 3. Büyük holdingidir. Üyelerinin yarısından çoğu astsubay olmasına rağmen 7 kişilik yönetim kurulunda bir astsubay ile temsil edilmeleri astsubaylar arasında huzursuzluk sebebidir. Son yıllarda Silahlı Kuvvetlerdeki profesyonelleşme ile büyük sayılara ulaşan OYAK üyesi uzman erbaşların yönetim kurulunda hiçbir temsilcilerinin olmaması da eleştiri konusudur.

OYAK’a bağlı şirketler büyük oranda siviller tarafından yönetilmekte ancak yönetim kurullarında emekli general/amiraller başta olmak üzere emekli subaylar görev almaktadır. ${ }^{21}$

OYAK Kanunu gereği (md. 18), daimî üye aylık maaşlarından kesilen yüzde 10'lar OYAK'ın önemli gelir kaynağını oluşturmaktadır. OYAK, bir zorunlu tasarruf kurumu ve bir ek sosyal güvenlik ve hizmet kurumu olarak kurulduğu halde, bugün ağırlıklı olarak sanayi olmak üzere, finans ve hizmet sektörlerinde faaliyet gösteren çeşitli şirketlere ortak olan bir holding haline gelmiştir. Bu şirketlerden sanayi şirketleri, demir-çelik, enerji, kimya, çimento, otomotiv, akaryakıt dağıtımı ve gıda sektörlerinde, hizmet şirketleri ise, inşaat, lojistik, turizm ve özel güvenlik sektörlerinde, finansal şirketleri ise bankacılık, menkul kıymet ve portföy yönetimi ile finansal kiralama konularında faaliyet göstermektedir. ${ }^{22}$

OYAK her yıl üye birikimlerini ettiği kâr oranında nemalandırmaktadır. Emeklilik yardımı nema oranı 1986'dan itibaren enflasyonun üzerinde seyretmiş (1991 ve 1994 hariç), 2003 yılından itibaren de enflasyonun iki katından fazla (2011 hariç) artış göstermiştir. 2007 yılında OYAKBANK’ın satılması ile nema oranı yüzde 54,2 gibi yüksek bir orana yükselmiştir.

OYAK bir sanayi holdingi olduğundan, TSK personelinin her yıl bu şirketlerin kârlarından aldığı nemalar, onları farkında olmadan sanayi sermayesinin yanında yer almaya zorlamaktadır. İdris Küçükömer, 1968 yılında, Düzenin Yabancılaşması

Denemesi”, Türkiye'de Ordu, Devlet ve Güvenlik Siyaseti, der., Evren Balta Paker ve İsmet Akça, İstanbul, Bilgi Üniversitesi Yayınları, 2010, s.384.

20 “Ordu Yardımlaşma Kurumu Kanunu”, Resmi Gazete, sayı 10702, 9 Ocak 1961, erişim 21 Mart 2021, https://www.resmigazete.gov.tr/arsiv/10702.pdf.

${ }^{21} 2011$ yılına kadar, terfi sırasında olup Askeri Şura'da terfi edemeyen ve emekli olan general/amirallerin nerdeyse tamamı, üç yıl boyunca bir OYAK grup şirketinde yönetim kurulunda görev yapmakta ve ayda bir toplantıya katılarak ikinci bir maaş elde etmekteydiler.

${ }^{22}$ Köktürk, Türkiye’de Ordu, s.188. 
eserinde, "OYAK’’n subayları kapitalist yapma girişimi olduğunu ve bu şekilde devam edilirse, subayların bir kısmının geniş halk kitlelerinin karşısına düşebileceğine" dikkat çekmiştir. ${ }^{23}$

Bu oluşuma TBMM içinden ciddi tek eleştiri de yine 1968 yılında, o tarihte Cumhuriyet Senatosu üyesi olan, eski bir MBK üyesi Cemal Madanoğlu'ndan gelmiştir. Kontenjan Senatörü Madanoğlu senatoda yaptığı konuşmada; "OYAK sayesinde subayların halktan koparak, paragöz durumuna düşeceklerin” belirtmiştir. ${ }^{24}$

OYAK üzerine yapılan eleştirilerden birisi de OYAK yüzünden ordunun sermaye içi çatışmaların içine çekilebileceğidir. Bu konuya dikkat çeken yazarlardan birisi olan Taha Parla; "ordunun büyük sermaye ile benzer ekonomik amaçlara sahip girişimciler olmasının ortak siyasi sonuçları olacağından kısa vadede büyük sermaye ile bir çelişki yaşanmayacağını, ancak ekonomide krizler yaşanıp pazar daraldığında uzun vadede sorunların su yüzüne çıkacağını" belirtmektedir. ${ }^{25}$

Son dönemde Avrupa Birliği (AB) çevrelerince dile getirildiği söylenen ve bazı sermaye kesimlerince de desteklenen ordunun holding ve banka sahibi olmasına karşı çıkan görüşlerin nedenlerinden birisinin de sermaye içindeki kâr paylaşımına yönelik olduğu düşünülebilir. Benzer olarak 28 Şubat sürecinde İslamcı sermayenin gelişmesinin büyük sermayeye olduğu kadar, büyük sanayi sermayesi ile çıkar birlikteliği içinde olan OYAK için de tehdit oluşturduğu düşüncesi dile getirilmiştir. Örneğin İsmet Akça; 28 Şubat sürecinde, "sınıfsal çıkarların devam ettirilmesi uğruna kültürel-ideolojik motiflerin kullanıldı̆̆ını”26 vurgulamaktadır. Bu süreçte irtica ile mücadele altında sermaye içi fraksiyon çatışması yaşandığı söylenebilir.

TSK'nin üretim sürecinde sermaye tarafında yer alması, emek tarafında yer alan sendikalar başta olmak üzere birçok kesim tarafından eleştirildiği gibi, kendi iç işleyişinin de olumsuz etkileyeceği değerlendirilmektedir.

Kısaca, OYAK; "TSK'nın birikim rejimi krizlerinde sanayi sermayesinin yanında yer almasına aracılık eden, TSK üst kademesini iş dünyası ileri gelenleri ile tanıştıran, ayrıca sahip olduğu üretim araçları ve dağıttığı nemalarla, düşük rütbeli TSK personeli dâhil ordunun çoğunluğunun sınıfsal yapısının değişmesine yol açan bir kuruluştur." 27

Emekli generallerin istihdam edildiği yerlerden birisi de özel şirketlerin yönetim kurulu üyelikleridir. 1990'ların sonuna kadar emekli general/amiraller devlet kurumları ile olan ilişkilerde kolaylık sağlamak maksadıyla çoğunlukla banka ve holdinglerde istihdam edilmişlerdir. Ancak 2000’li yıllardan başlayarak emekli generallerin istihdam edildikleri alanların bilhassa savunma sanayi şirketleri, TSKGV ile ilgili şirketler, TSK Vakıfları ve OYAK şirketleri ile sınırlı kaldığı görülmektedir. Bunun sebeplerinin, 1990'ların sonunda baş gösteren bankacılık krizi ile bankacılığın daha profesyonel kadrolar oluşturmasının, dönemin Genel Kurmay Başkanı Orgeneral Kıvrıkoğlu döneminde emekli generallerin banka yönetim kurullarında

\footnotetext{
${ }^{23}$ İdris Küçükömer, Düzenin Yabancılaşması, İstanbul: Bağlam Yayınları, 2002, s.115-117.

${ }^{24}$ Köktürk, Türkiye'de Ordu ve Sermaye, s.186.

${ }^{25}$ Taha Parla, “Türkiye'de Merkantilist Militarizm (1960-1998)”, Bir Zümre, Bir Parti, Türkiye’de Ordu, Birikim'den Seçmeler:2, İstanbul: Birikim Yayınları, der., Ahmet İnsel ve Ali Bayramoğlu, 2004, s.206.

${ }^{26}$ İsmet Akça, "Kolektif Bir Sermayedar Olarak Türk Silahlı Kuvvetleri”, Bir Zümre, Bir Parti, Türkiye’de Ordu, Birikim'den Seçmeler:2, İstanbul: Birikim Yayınları, der., Ahmet İnsel ve Ali Bayramoğlu, 2004, s.266.

${ }^{27}$ Köktürk, "Militarizmin Öteki Yüzü”, s.90.
} 
çalışmasının yasaklanmasıyla ve AK Parti’nin güçlü bir hükümet kurmasıyla, şirketlerin devlet ile ilişki kurmasında emekli askerlerden ziyade sivil siyasetçileri öne çıkmaları ile alakalı olduğu düşünülebilir.

Türkiye'de TSK, bilhassa savunma sanayi şirketleri ile üst düzey kadrolarıyla irtibattadır. Savunma harcamalarında olduğu gibi, askeri ihaleler ve projelerde de kontrolün TSK'nın elinde olması sivil sermayenin elindeki savunma sanayi şirketlerinde istihdam edilen üst düzey subayların önemini arttırmıştır.

Askeri fabrikalar haricinde KİT, SSM veya TSGV şirketleri ile savunma sanayinde proje üreten özel şirketler ile yabancı ortaklı şirketlerde proje koordinatörü başta olmak üzere çeşitli kadrolarda emekli askerler istihdam edilmişlerdir.

Savunma sanayinde sivil girişimcilerin yanında TSK'nın de sermaye olarak hareket etmeye başlaması Türk Silahlı Kuvvetlerini Güçlendirme Vakfı'nın (TSKGV) kurulması iledir. Bu vakfın bünyesi altında veya büyük ortağı olduğu şirketler direkt savunma sanayine yatırım ve üretim yapmaktadırlar.

TSKGV'nin 6 adet bağlı ortaklığı, 7 adet iştiraki ortaklığı, 29 adet dolaylı bağlı ortaklığı ve 2 adet dolaylı bağlı ortaklık şubesi vardır. Yani toplamda 44 adet şirketi TSKGV dolaylı veya doğrudan yönlendirmektedir. TSKGV'nin doğrudan ortak olduğu bazı şirketlere ASELSAN, Türk Havacılık ve Uzay Sanayii, ROKETSAN, HAVELSAN, ASPILLSAN ve İŞBİR'dir. HAVELSAN Teknoloji Radar, HAVELSAN EHSİM ve YİTAL ise TSKGV'na bağlı dolaylı ortak şirketlerdir. ${ }^{28}$

TSKGV teşkilat yapısında diğer TSK ile bağlantılı şirketlerde olduğu gibi hiyerarşik bir rütbe yapılanması vardır. Kuruluşundan itibaren TSKGV genel müdürlerinin emekli korgeneral, genel müdür yardımcılarının emekli tümgeneral, vakıf hizmetleri grup başkanlarının emekli tuğgeneral/tuğamiral (iki dönemdir tuğamiraldir), mali işler ve iştirakler grup başkanlarının ise emekli tuğgeneral olduğu görülmektedir.

Emekli generallerin istihdam edildiği TSKGV harici diğer askeri vakıflardan bazıları; TSK Elele Vakfı, TSK Sağlık Vakfı, TSK Eğitim Vakfı, Mehmetçik Vakfı ve Kartal Vakfıdır. Bu vakıflar Gülsav, Türktıpsan, Mehmetçik Sigorta, Tınaztepe Gayrimenkul Şirketi, Güngören Park Alışveriş Merkezi gibi şirketlerde toptan pazarlamadan, enjektör üretimine, sigortacilıktan gayrimenkul pazarlamaya ve AVM yönetimine kadar çeşitli kollarda faaliyet göstermektedirler.

Ancak son 10 yılda OYAK dâhil, askeri şirket ve vakıf yönetim kurullarında askerlerin sayısı gözle görülür şekilde düşmektedir.

\section{Askeri Şirketlerin Yönetim Kurulları ve Ordu Siyaset İlişkisinin Dönüisuimüi}

Çalışmanın başında söylediğimiz gibi, ordu yönetim kademesi her zaman güçlüye biat etmiştir. 2002 yılında iktidara gelen AK Parti'nin Türkiye'nin güçlü kurumu ordu ile de iktidarı paylaşması gerekmiş, ancak 2007 de başlayan Ergenekon ve 2010'da başlayan Balyoz davaları ordunun AK Parti'nin gücünü görmesini sağlamıştır. 2014 yılında davaların tüm sanıkları serbest kalmış, ancak 15 Temmuz 2016'daki kalkışma sonucunda TSK'dan 30 bine yakın subay/astsubay ihraç edilmiştir. 
TSK bu olaylar ile uğraşırken OYAK'ın 16 yıllık Genel Müdürü Coşkun Ulusoy 2016 yılında istifa ettirilerek yerine AK Parti hükümeti tarafından önerilen Süleyman Savaş Erdem getirilmiştir. Peşinden 2016 yılı OYAK Genel Kurulu'nda önemli bir karar alınmıştır. Bu kararda "dünyada oluşan firsatlar konjonktürü sebebiyle” OYAK tarafından şirket ve varlık alımları yapılırken, OYAK'ın bu fırsatları gecikmeden değerlendirebilmesi için yurt içi 500 milyon TL, yurt dışı 300 milyon dolar olan alımlarda OYAK Yönetim Kuruluna yetki verilmiş, bu miktarların üzeri için Genel Kurul yetkili kılınmıştır. ${ }^{29}$

Bundan önce yatırım kararlarına Genel Kurulda karar verilmesine rağmen, bu kararla, belli limite kadar yatırım kararları kolay kontrol edilebilecek 7 kişilik yönetim kuruluna verilmiștir. Yönetim Kurulunun alım satımlara yönelik bu yetkisinin parasal sınırı 2017 ve 2018 Yılı Genel Kurulunda yükseltilmiştir. Yönetim Kurulu Yetki Sınırı, 2017 Genel Kurulunda Kurum Net Varlığının \% 20’sine yükseltilmiştir. ${ }^{30} 2018$ 'de ise bu yetki Kurum Net Varlığının \% 30'una çıkarılmıştır. ${ }^{31} \mathrm{Bu} 50$ Milyar TL net varlık üzerinden hesaplandığında, Yönetim kuruluna yaklaşık 2 Milyar dolarlık alım yetkisi vermek demektir.

OYAK Yönetim Kurulu bu yetkisini, 2020 yılında Demirören grubuna ait akaryakıt dağıtım şirketi TOTAL'i ve Likit Petrol gazı dağıtımı yapan Milangaz'ı ayrı ayrı 450 milyon dolara alarak kullanmıştır. Demirören grubunun iktidara yakın medyaya sahip olması ve bu medya grubunu satın alırken Ziraat Bankası'ndan aldığı 700 milyon dolar krediyi ödemekte zorlanmasının bu alımda etken olduğu değerlendirilmektedir. Bu alım ile OYAK 2020 nemasının beklenenin 15 puan altında çıkması ile OYAK üyeleri arasında OYAK kaynaklarının iktidarın yönlendirmesi ile kullanıldığı kanaati oluşmuştur. Bazı üyeler bu durumu OYAK’a gönderdikleri dilekçeler ile protesto ederken, bazıları ise Ankara'daki OYAK Genel Müdürlügüu önünde gösteri yaparak protesto etmişlerdir. 2021 yılı Mart ayında bu sefer gida sektörünün zor durumdaki şirketi Sagra'yı siyasetin isteği ile alması, OYAK kaynaklarının zor durumdaki şirket alımlarında kullanılacağı konusundaki kuşkuları arttırmıştır. $^{32}$

TSKGV bağlısı şirketlerde yönetim kurulu başkanının emekli general olması geleneği, 2014 genel kurulundan itibaren Aselsan yönetim kurulu başkanlığına bir sivilin seçilmesi ile geçerliliğini yitirmiştir. Aynı şekilde 2016 yılından itibaren MKEK genel müdürlügü de sivilleşmiştir. Havelsan yönetim kurulu başkanı da artık emekli general değildir.

Aşağıdaki tabloda, yıllar itibari ile bazı TSKGV ve OYAK'ın ortaklığı bulunan şirket yönetim kurullarında görev alan asker ve sivil sayıları gösterilmiştir.

Tablo 1. DİTAŞ, ASELSAN, HAVELSAN, TUSAŞ, TUSAŞ TAİ, ROKETSAN, İŞBİR, OYKA, Hektaş, Ünye Çimento, Aslan Çimento, Adana Çimento, OYAK Beton, Mardin Çimento, Bolu Çimento, OYAK Çimento Yönetim Kurullarında Görev Alan Asker-Sivil Sayısının Yıllara Göre Dağlımı ve Asker/Sivil Üye Oranları.

\begin{tabular}{|c|c|c|c|c|c|c|c|}
\hline & Asker & Sivil & Asker/Sivil & & Asker & Sivil & Asker/Sivil \\
Yıllar & Üye & Üye & Üye Oranı & Yllar & Üye & Üye & Uye Oranı \\
\hline
\end{tabular}

29 “Genel Kurul Kararları”, OYAK Dergisi, 131, Haziran 2016, s.47.

30 “Genel Kurul Kararları”, OYAK, 57’nci Olağan Genel Kurul Bülteni, Mayıs 2017, s.48.

31 "Genel Kurul Kararları”, OYAK 58'nci Olağan Genel Kurul Bülteni, Mayıs 2018, s.74.

32 "OYAK Gıda Sektörünün Öncü Şirketi Sagra’yı Satın Aldı”, Hürriyet Gazetesi, erişim 29 Mart 2021, https://www.hurriyet.com.tr/ekonomi/oyak-gida-sektorunun-oncu-sirketi-sagrayi-satin-aldi-41774410. 


\begin{tabular}{|c|c|c|c|c|c|c|c|}
\hline & Sayısı & Sayısı & $(\%)$ & & Saylst & Sayısı & $(\%)$ \\
\hline 1978 & 3 & 13 & 23 & 2000 & 35 & 45 & 78 \\
\hline 1979 & 5 & 10 & 50 & 2001 & 37 & 38 & 97 \\
\hline 1980 & 6 & 13 & 46 & 2002 & 31 & 46 & 67 \\
\hline 1981 & 6 & 14 & 43 & 2003 & 31 & 57 & 54 \\
\hline 1982 & 9 & 15 & 60 & 2004 & 30 & 61 & 49 \\
\hline 1983 & 10 & 13 & 77 & 2005 & 35 & 53 & 66 \\
\hline 1984 & 12 & 17 & 71 & 2006 & 38 & 45 & 84 \\
\hline 1985 & 11 & 22 & 50 & 2007 & 32 & 48 & 67 \\
\hline 1986 & 9 & 21 & 43 & 2008 & 31 & 50 & 62 \\
\hline 1987 & 10 & 20 & 50 & 2009 & 33 & 48 & 69 \\
\hline 1988 & 9 & 26 & 35 & 2010 & 37 & 47 & 79 \\
\hline 1989 & 14 & 42 & 33 & 2011 & 38 & 48 & 79 \\
\hline 1990 & 14 & 49 & 29 & 2012 & 39 & 50 & 78 \\
\hline 1991 & 20 & 53 & 38 & 2013 & 30 & 61 & 49 \\
\hline 1992 & 18 & 46 & 39 & 2014 & 27 & 65 & 42 \\
\hline 1993 & 17 & 61 & 28 & 2015 & 25 & 58 & 43 \\
\hline 1994 & 22 & 62 & 35 & 2016 & 26 & 66 & 39 \\
\hline 1995 & 26 & 57 & 46 & 2017 & 21 & 68 & 31 \\
\hline 1996 & 29 & 59 & 49 & 2018 & 20 & 70 & 29 \\
\hline 1997 & 33 & 55 & 60 & 2019 & 13 & 71 & 18 \\
\hline 1998 & 31 & 51 & 61 & 2020 & 12 & 84 & 14 \\
\hline 1999 & 30 & 54 & 56 & & & & \\
\hline
\end{tabular}

Kaynak: Ticaret Sicil Gazetesi ${ }^{33}$ ve şirketlerin Kamu Aydınlatma Platformu'na (KAP) gönderdikleri yönetim kurulu listeleri ${ }^{34}$

Aşağıdaki grafikte, Tablo 1 kullanılarak TSKGV ve OYAK’’n ortaklığı bulunan bazı şirket yönetim kurullarında görev alan üyelerin asker/sivil oranlarında yıllara göre değişim gösterilmiştir.

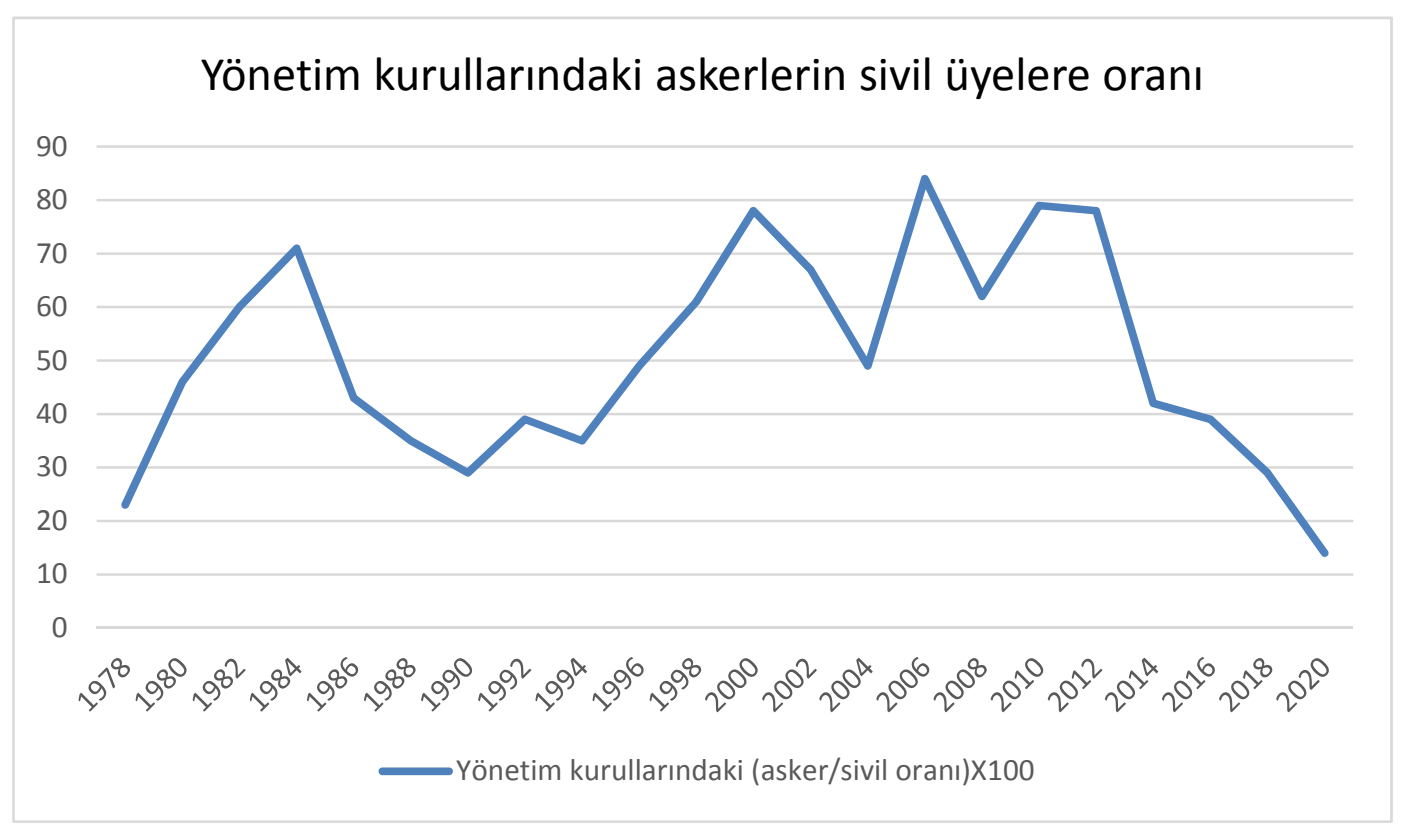

Grafik 1. TSKGV ve OYAK'ın ortaklığı bulunan bazı şirket yönetim kurullarında görev alan asker üyelerin, sivil üyelere oranında yıllara göre değişim.

\footnotetext{
33 "Şirket Bilgileri”, Türkiye Ticaret Sicil Gazetesi, erişim 15 Mart 2021, http://www.ticaretsicil.gov.tr.

34 “Tüm Şirketler”, Kamuyu Aydınlatma Platformu, erişim 26 Mart 2021, http://kap.gov.tr/sirketler/islemgoren-sirketler/tum-sirketler.aspx.
} 
$\mathrm{Bu}$ tablo ve grafikler incelendiğinde, askeri müdahalelerin olduğu 12 Eylül 1980 'den ve 28 Şubat sürecinden sonra yönetim kurullarında asker/sivil oranının askerler lehine arttığı, son 10 yıldır ise azaldığı görülmektedir.

\section{Sonuç}

Türkiye'de ordunun ekonomi ve siyaset ile ilişkisi tarihsel bir gerçekliktir. Ordu siyasete yaptığı müdahaleler ile iktidarları değiştirmiş, OYAK ile üretim aracı sahibi de olduğundan sanayi sermayesine eklemlenmiştir. Müdahalelerden çoğunlukla sanayi sermayesinin fayda sağlamasının sebepleri ayrıca tartışılmalıdır.

Askeri müdahalelerin bir özelliği de birikim rejimleri ile olan ilişkisidir. 27 Mayıs 1960 müdahalesi ticaret sermayesinin hegemonyasına son verirken, aynı zamanda yürürlükte olan ithal ikameci sanayileşme birikim rejiminin işleyişini hızlandırmıştır. 27 Mayıs müdahalesini yapanların ilk icraatlarından birisi kaynakların sanayi sermayesince kullanılmasını sağlayacak DPT’nin kurulması, diğeri de askerlerin üretim aracı sahibi gibi davranmalarını sağlayacak OYAK’ın kurulmasıdır.

İthal ikameci sanayileşmenin 1970’lerin başında girdiği kriz, 12 Mart 1971 müdahalesi ile yine sanayi sermayesi lehine çözülmüştür. 12 Eylül 1980 ise, 24 Ocak 1980'de alınan ekonomik kararların otokratik bir rejimde uygulamasını kolaylaştırmış ve ihracata yönelik sanayileşme birikim modelinin uygulanmasını kolaylaştırmıştır. 12 Eylül aynı zamanda iktidar blokunda sanayi sermayesinin tek başına hakimiyet kurmasını da sağlamıştır.

28 Şubat sürecindeki sermaye içi kar paylaşım savaşında kültürel ve ideolojik söylemler kullanarak ticaret sermayesine karşı sanayi sermayesinin yanında yer alan ordu, muhafazakâr kitlenin 2002 seçimlerinde AK Parti'yi iktidara taşımasının önünü açmıştır. Bununla beraber, 2007 de başlayan Ergenekon, 2011 yılındaki Balyoz davaları ve 15 Temmuz 2016 darbe girişimi süreçleri ile ordu-siyaset ilişkileri yeniden şekillenmiştir.

Askeri şirketler yönetim kurullarındaki asker/sivil üye oranları yıllar itibari ile incelendiğinde, askeri müdahale ve askere müdahale dönemlerinde kırılmalar olduğu görülmektedir. 12 Eylül 1980 ve 28 Şubat sürecinde TSKGV ve OYAK şirket yönetim kurullarında asker üye sayıları artarken, 2011 yılındaki Balyoz davasından itibaren yönetim kurullarındaki sayının askerler aleyhine bozulduğu, bu durumun 15 Temmuz girişiminden sonra hızlandığı, 2020 yılında da artarak devam ettiği görülmektedir.

TSKGV ve OYAK şirketlerindeki sivilleşme, gerçek bir profesyonelleşme yerine, yönetim kurulu başkanı olan emekli korgenerallerin yerine, eski milletvekilleri veya bir şekilde iktidar ile iltisaklı kişilerin atanması şeklinde olmaktadır. Bu sivilleşmenin bir yönü de, artık TSKGV ve OYAK şirketlerinde işe alınacaklara emekli generallerin değil, siyasetin karar vermesi olarak da gözükmektedir.

OYAK ve askeri vakıf şirketleri yönetim kurullarındaki sivilleşme, ordunun üretim aracı sahipliğini etkilememiş, sadece yatırımların siyasi iktidar kontrolünde yapılmasını sağlamıştır. Siyasi iradenin askeri şirket yönetim kurullarına askerler yerine sivilleri yerleştirmesi durumu, OYAK nemaları gerçek enflasyonun birkaç puan üzerinde seyretmesi halinde çok sorun yaratmayacaktır. Ancak nemaların beklentilerin altında seyretmesinin bilhassa ordu alt rütbelerdeki personelde huzursuzluğa sebep olacağı değerlendirilmektedir. 
Askeri şirketlerdeki kırılma olarak 2011 yılının alınmasının sebebi, o yıl başlayan Balyoz davasıdır. Bu dava sürecinde eski Genel Kurmay Başkanı dâhil, yüzlerce amiral, general ve yüksek rütbeli subay ortalama 4 yıl hapis yatmışlardır. 2011 yılında başlayan Balyoz davası ile, yargılanan üst rütbeli subay sayısı olarak en yüksek sayıya ulaşmıştır.

2011 yılında aynı zamanda Türkiye'nin güney komşusu Suriye'de iç karışıklıklar başlamıştır. Türk ordusu 2015-2020 yılları arasında Suriye'de 6 ayrı harekât yapmıştır. Balyoz Davası, bu süreçte Türk ordusunun Suriye'de kullanılmasına karşı çıkabilecek olası kadroların tasfiyesini sağlamış olabileceği gibi, ordu üzerinde sivil kontrolü sağlamaya da yardımcı olmuştur.

Bu süreçte, askeri şirketlerdeki sivilleşme yanında ordu-siyaset ilişkisinin dönüştüğünü gösteren başka göstergeler de bulunmaktadır. Temmuz 2016'da Kuvvet Komutanlarının, 2018 yılında da Genel Kurmay Başkanlığı'nın Milli Savunma Başkanlığı'na bağlanması askerler üzerinde siyasi otoritenin kurulması açısından önemlidir. Bugün için Milli Savunma Bakanı’nın emekli Genel Kurmay Başkanı olması bu geçişi kolaylaştırmış gözükmektedir.

\section{Kaynakça}

Akça, İsmet. "Kolektif Bir Sermayedar Olarak Türk Silahlı Kuvvetleri”. Bir Zümre, Bir Parti, Türkiye'de Ordu, Birikim'den Seçmeler: 2. Der., Ahmet İnsel ve Ali Bayramoğlu. İstanbul: Birikim Yayınları, 2004: 225-269.

Akça, İsmet. "Ordu, Devlet ve Sınıflar: 27 Mayıs 1960 Darbesi Örneği Üzerinden Alternatif Bir Okuma Denemesi”. Ordu, Devlet ve Güvenlik Siyaseti. Der., Evren Balta Paker ve İsmet Akça. İstanbul, Bilgi Üniversitesi Yayınları, 2010: 351-406.

Avcıŏlu, Doğan. Türkiye’nin Düzeni, 1. Kitap. İstanbul: Tekin Yayınevi, 11. bs., 1977.

Çelik, Bülent. "Yeniçerilerin Esnaflaşmasında Orducu Görevinin Rolüne Dair Bazı Tespitler". Belgi Dergisi. 2/18 (2019): 1683-1700.

“Genel Kurul Kararları”. OYAK Dergisi. 131 (2016).

“Genel Kurul Kararları”. OYAK, 57’nci Olağan Genel Kurul Bülteni. (2017).

“Genel Kurul Kararları”. OYAK, 58'nci Olağan Genel Kurul Bülteni. (2018).

Gevgilili, Ali. Yükseliş ve Düşüş. İstanbul: Altın Kitaplar, 1981.

Hale, William. Türkiye'de Ordu ve Siyaset. Çev., Ahmet Fethi. İstanbul: Hil Yayınları, 1996.

Jessop, Bob. "Accumulation Strategies, State Forms, and Hegemonic Projects". Kapitalistate. 10/11 (1983): 89-112.

Köktürk, Abdullah. "Militarizmin Öteki Yüzü: Askeri Şirketler”. Ayrıntı Dergisi. 31 (2019): 82-91.

Köktürk, Abdullah. Türkiye'de Ordu ve Sermaye İlişkisi. Ankara: Nobel Bilimsel Eserler, 2. bs., 2019.

Köktürk, Abdullah. “Türkiye'de İktidar Bloğu'nun Değişim ve Dönüşümleri”, ICHES Uluslararası Insani Bilimler ve Eğitim Bilimleri Kongresi Tam Metin Kitabı. Elazığ: Asos Yayınevi, 2019: 693-706.

Küçükömer, İdris. Düzenin Yabancılaşması. İstanbul: Bağlam Yayınları, 2002.

“Ordu Yardımlaşma Kurumu Kanunu”. Resmi Gazete, sayı 10702, 9 Ocak 1961. 
Erişim 21 Mart 2021. https://www.resmigazete.gov.tr/arsiv/10702.pdf.

“OYAK Gıda Sektörünün Öncü Şirketi Sagra’yı Satın Aldı”. Hürriyet Gazetesi. Erişim 29 Mart 2021. https://www.hurriyet.com.tr/ekonomi/oyak-gidasektorunun-oncu-sirketi-sagrayi-satin-aldi-41774410.

Özer, M. Halis, "Cumhuriyetin İlk Yıllarında Millî Tüccar Oluşturma Çabalarında İş Bankası'nın Rolü”. Ankara Üniversitesi SBF Dergisi. 69/2 (2014): 351-377.

Parla, Taha. “Türkiye'de Merkantilist Militarizm (1960-1998)”. Bir Zümre, Bir Parti, Türkiye'de Ordu, Birikim'den Seçmeler: 2. Der., Ahmet İnsel ve Ali Bayramoğlu. İstanbul: Birikim Yayınları, (2004): 201-223.

Savran, Sungur. “1960, 1971, 1980 Toplumsal Mücadeleler, Askeri Müdahaleler”. 11. Tez Kitap Dizini, 6, İstanbul: Uluslararası Yayınc1lı. 1987: 132-168.

Şener, Abdüllatif. “İttihat ve Terakki Cemiyeti’nin İktisadi ve Mali Politikaları”. Hacettepe Üniversitesi İktisadi ve İdari Bilimler Fakültesi Dergisi. 8/1 (1990): 203-232.

“Şirket Bilgileri”. Türkiye Ticaret Sicil Gazetesi. Erişim 15 Mart, 2021. http://www. ticaretsicil.gov.tr.

“TSKGV Şirketler Grubu”. TSK Güçlendirme Vakfı Dergisi. (2014).

“TSK İç Hizmet Kanunu”. Erişim 26 Mart, 2021. http://www.mevzuat.gov.tr/ MevzuatMetin/1.4.211.pdf.

“Tüm Şirketler”. Kamuyu Aydınlatma Platformu. Erişim 26 Mart, 2021. http://kap.gov.tr/sirketler/islem-goren-sirketler/tum-sirketler.aspx.

Weber, Max. Sosyoloji Yazıları. Çev., Taha Parla. İstanbul: Deniz Yayınları, 2008. 